\title{
Home Food Gardening in Canada in Response to the COVID-19 Pandemic
}

\author{
Lisa Mullins ${ }^{1}$, Sylvain Charlebois ${ }^{2}$, Erica Finch ${ }^{1}\left[\right.$ and Janet Music ${ }^{2, *}$ \\ 1 Faculty of Management, Dalhousie University, Halifax, NS B3H 4R2, Canada; lmullins@dal.ca (L.M.); \\ Erica.Finch@dal.ca (E.F.) \\ 2 Faculty of Agriculture, Dalhousie University, Halifax, NS B3H 4R2, Canada; sylvain.charlebois@dal.ca \\ * Correspondence: jlmusic@dal.ca
}

Citation: Mullins, L.; Charlebois, S.; Finch, E.; Music, J. Home Food Gardening in Canada in Response to the COVID-19 Pandemic.

Sustainability 2021, 13, 3056.

https://doi.org/10.3390/su13063056

Academic Editor: Colin Michael Hall

Received: 27 January 2021

Accepted: 3 March 2021

Published: 11 March 2021

Publisher's Note: MDPI stays neutral with regard to jurisdictional claims in published maps and institutional affiliations.

Copyright: (c) 2021 by the authors. Licensee MDPI, Basel, Switzerland. This article is an open access article distributed under the terms and conditions of the Creative Commons Attribution (CC BY) license (https:// creativecommons.org/licenses/by/ $4.0 /)$.

\begin{abstract}
The lack of academic attention that home food gardening has received in Canada and the United States is surprising, given the many demonstrated benefits of community gardening programs, including increased community cohesion and resilience. The aim of the exploratory study is to explore the current surge in home food gardening and its relationship to the COVID-19 pandemic. A national survey was conducted, consisting of 43 main questions, asking respondents about their home life and food provisioning during COVID-19, the physical characteristics of their food gardens, and their attitudes and beliefs concerning home food production. Survey results show that $51 \%$ of respondents grow at least one type of fruit or vegetable in a home garden. Of those, $17.4 \%$ started growing food at home in 2020 during COVID-19 pandemic. To gain more insight into just how significant a cause the pandemic lockdown was on home food gardening, follow-up surveys and policy recommendations are suggested.
\end{abstract}

Keywords: home gardening; home food production; COVID-19; fruits and vegetables; Canada

\section{Introduction}

Home food gardening in Canada, whether a vegetable patch in the backyard or a pot of cherry tomatoes on the kitchen windowsill, has long been an innocuous activity outside the realm of academic interest. However, food gardening behaviours have taken on a new significance following the outbreak of the COVID-19 pandemic. Garden retailers have reported exponential increases in sales, in some cases up to $450 \%$ [1]. Much of these sales represent new gardeners, mainly millennials, purchasing supplies to establish household food gardens [1-3]. Perhaps not surprisingly, this led to a preserving and canning supply shortage in many parts of Canada, with entire provinces in the Maritimes completely out of jars and lids [4].

Prior to 2020, not much attention was given to gardening in Canada. In fact, few knew what the home gardening rate was in Canada, prior to the pandemic. The aim of the exploratory study is to explore the current surge in home food gardening and its relationship to the COVID-19 pandemic. The objectives of this study are threefold: (1) to discover the scope and extent of home food production in Canada; (2) to examine the underlying factors that have led some Canadians to react to COVID-19 by gardening; and (3) to explore attitudes toward home food gardening, especially those who started gardening during the COVID-19 pandemic. The paper first looks at gardening and past studies on the matter. It presents how the cross-national survey was designed. Findings, a discussion, and future research paths are also included in the current paper.

\section{Gardening}

This exploratory study defines a home food garden as one where at least one fruit or vegetable is grown on property attached to the residence of the grower. The property may be owned, rented, or borrowed, and the garden space can be a backyard, front yard, 
balcony, or windowsill, either outside or inside. Unlike a community garden, a home food garden is managed by a single household by at least one member of that household regardless of socio-demographic characteristics.

The global food supply system has been under scrutiny since the advent of the COVID19 pandemic. Fears of food shortages have led consumers to panic buy and stockpile [5]. Online grocery shopping saw a boom as consumers shied away from brick- and-mortar alternatives. High-volume meat production plants were shuttered as workers experienced serious outbreaks of the disease [6]. While consumers feared the collapse of the food supply chain, as the pandemic wore on it became clear that despite some minor inconveniences brought on by a surge of home cooking and baking, consumers would still have access to a full and varied supply of food [7].

Despite the apparent resiliency of the food supply in Canada, the COVID-19 pandemic has brought the globalized food supply to the attention of consumers, though the full complexity of the supply chain likely remains incomprehensible to the average consumer. Food supply is a vertically integrated system organized around creating value for the end consumer [8]. This includes farmers who grow and harvest the raw materials, but also the processing, packaging and distribution systems. In addition, food items are subject to global trading, which further adds to complexity of the food supply and traceability of food products, especially in times of crisis [9]. Still, many people began exploring options to insulate their household from shocks to the global food supply.

The practice of home food gardening in Canada has remained largely unscrutinised by researchers. While the National Gardening Association [NGA] conducts regular surveys to characterize the state of home food gardening in the United States, the nearest comparable efforts in Canada fall far short of their example. A biennial survey conducted by Statistics Canada asks respondents whether they "Grew fruit, herbs, vegetables or flowers for personal use in the past 12 months" [10], and while the survey revealed that $57 \%$ of Canadians engage in some form of gardening, the inclusion of flowers within the wording of the question obscures exactly how many of those gardeners are growing food. A 2002 survey revealed that $40 \%$ of Toronto residents and $44 \%$ of Vancouver residents grow food at home or in a community garden [11]. Here it is worth noting that only $3 \%$ of respondents to the Statistics Canada 2017 survey report using a community garden, versus the $80 \%$ who grow in a yard, the $29 \%$ who grow on a balcony, or the $20 \%$ who grow indoors [10]. Regionally, the Laboratory on Urban Agriculture (AU/LAB), (2019) carried out a mapping study of satellite images of home gardens in an urban and suburban district of Quebec that includes Montreal. They found that in a borough of 32,345 lots of land, only 5\% of properties had identifiable vegetable gardens [12]. Even accounting for those households who are only growing flowers, it is certain that the majority of Canadians who grow food for personal use do so at home rather than in a community garden.

Yet despite the likelihood that more food gardeners probably grow food at home, to date academia has shown far more interest in community gardening. The period between 1985 and 2011 saw 46 peer-reviewed articles published on the topic of food growing in community gardens in the United States [13], while that same space of time saw only 5 articles on home food gardens [14]. The ensuing years have not produced much new research on community gardens, though there is enormous potential for both qualitative research and research into the financial benefits community gardening [15]. Only one peer reviewed article has been published on home food gardening in Canada: a qualitative study of backyard food gardens and food security in Toronto [16]. Reasons for this lack of interest may include the perceived triviality of home food gardening [14], or the time-consuming and difficult process of identifying households with food gardens for study [16-18]. Studies are further complicated by the abundance of ways that home food gardens manifest themselves, making considerations such as location, function, gardening methods, and size just a few considerations for defining a sample [14].

The lack of academic attention that home food gardening has received is surprising, given the many demonstrated benefits of urban community gardening programs, including 
increased community cohesion and resilience [19,20], increased food security [21] increased physical health [22-24]; and increased mental health [23,24]. Similar benefits have also been observed in home food gardens of the Global South [25], where interest in household food security in regions experiencing civil, economic, or ecological disruption has prompted academic interest in home food gardening. Food security has been a major concern of the few researchers looking at home food gardens $[16,18,26-28]$.

Motivations for growing food at home can be complex and varied. Some researchers place these motivations on a spectrum, with food security at one end and leisure activity at the other [27]. It is certainly true that the handful of studies investigating home food gardening practices have demonstrated consistent interest in its contribution to household food security. However, even these few studies have revealed a multitude of motivations for growing food at home that do not sit comfortably on such a spectrum: when asked why they grow food, gardeners may cite ecological concern and a desire to engage in responsible food production [16,29-31], a desire to engage with their community [16,32-34], a need for food security $[14,26,28,35,36]$, the physical and emotional benefits of being in the garden [16,32], or a combination thereof. In fact, Kortright and Wakefield's 2011 study of home food gardening and food security in the city of Toronto ultimately revealed that none of the study participants were reliant on their gardens for food-if their plants failed, the participants simply bought what they needed at the store instead.

Nevertheless, there are links between times of economic hardship and increases in home food gardening. Most recently, the Great Recession in 2008 saw the emergence of the term "crisis garden," which has been used to describe food gardens planted by households in response to some form of disaster that threatens their food security [3,37]. The five-year period following the Great Recession saw a 17\% spike in home food gardening in the United States [38]. Precedents to the modern crisis garden can be found in the gardening movement of the 1970s [39], Victory Gardening in the world wars [40] and in the Relief Garden movement of the Great Depression [40]. Governments have a keen understanding of the role that home gardening can play in supporting and supplementing industrial food systems. Especially in the Second World War, the Victory Garden program had prolific success in supporting the war effort by, most significantly, uniting communities around a common goal-Victory in Europe-and sending food overseas to the frontlines and other Allied countries [40]. In 2020, the global COVID-19 pandemic has rekindled this sentiment in certain segments of the population [3].

Schupp and Sharp (2012) note that home food gardening as a response to economic hardship is not a strategy solely employed by lower income households but is in fact utilized within every income bracket. However, food insecurity or financial hardship alone are seldom the main determinants to home food gardening. Previous exposure to and knowledge of food gardening is also an indicator that a household may decide to grow their own food. Individuals living within a community where home food gardening is embedded in the community culture $[27,28,33]$, or individuals who grew up in a rural area or on a farm [16] are more likely to grow food themselves. It is also notable, however, that even within communities where gardening is common, the poorest households in Canada are the least likely to grow their own food [33]. Statistics Canada (2020) reports a $5 \%$ increase in the rate of household food insecurity during the current pandemic compared to 2017/2018 levels: it is clear that COVID-19 has had a significant impact on the ability of Canadian households to feed themselves [41]. Yet while more households than ever grapple with food insecurity, more people are turning to food gardening as a healthy hobby rather than a strategy to lower the grocery bill [2,3]. It appears that the results of a 2016 study still hold true: food insecure households are less likely to grow food at home and that home food gardening is not connected to the probability of food insecurity [42].

\section{Materials and Methods}

A questionnaire was developed to explore home food gardening in Canada. A survey was conducted online from 28 September 2020, to 30 September 2020, in French and English 
using a Qualtrics platform. The survey was administered by Angus Reid, a Canadian market research firm, with participants drawn from their 1.3 million self-selecting Canadian consumers. The Research Ethics Board at the researchers' home university approved the survey. 1023 valid responses collected, with any incomplete responses removed before analysis. The margin of error was $+/-3.1 \%, 19$ times out of 20, with any discrepancies in or between totals caused by rounding. Data were collected using a quota system based on Canadian national census data from 2016 of gender and population across six regions: British Columbia, the Prairies, Ontario, Quebec, the Atlantic Provinces, and the North.

This survey consisted of 43 main questions, asking respondents about their home life and food provisioning during COVID-19 (8 questions), the physical characteristics of their food gardens (21 questions), and their attitudes and beliefs concerning home food production (14 questions). Answer options for the first 29 questions consisted of yes / no or multiple choice, such as 'Did you grow vegetables and/or fruits at home before the COVID-19 pandemic? Yes or No'. For the questions surveying attitudes about home food gardening, questions took the form of statements, with respondents asked to indicate their relative agreement or disagreement using a Likert scale; for example, question 38: 'I grow food to reduce my environmental impact. Strong agree, somewhat agree, neither agree nor disagree, somewhat disagree, strongly disagree.' The survey also collected demographic information in 10 areas, including current housing type, geographic region of residence, and type of community (rural, urban core, suburban).

\section{Results}

Survey results show that $51 \%$ of respondents grow at least one type of fruit or vegetable in a home garden. Of those, $17.4 \%$ started growing food at home in 2020 during COVID-19 pandemic. $66 \%$ of new home food gardeners agree that the current pandemic influenced their decision to start producing food at home. $43 \%$ of home food gardeners spend $10 \mathrm{~h}$ or less a week gardening. Though there are commonalities between long-time food gardeners and new food gardeners, there are more significant differences, especially around attitudes about and motivations for home food growing.

\subsection{Time Spent at Home during the COVID-19 Pandemic}

The public health measures put in place in mid-March to contain the spread of COVID19, such as household-isolation and the closure of restaurants and entertainment venues, clearly influenced individuals to start home food gardening. $95.6 \%$ of new home food gardeners reported spending more time at home in 2020, and $62.2 \%$ also indicated they spent time working from home since the pandemic began. Only $46.3 \%$ of long-time gardeners reported working from home this year, and $84 \%$ indicated they spent more time at home this year than in the past.

\subsubsection{Gender}

$52.5 \%$ of respondents who grow food at home are women, $47.1 \%$ are men, and $0.4 \%$ identify as neither male nor female. These results are in line with respondents who do not grow any food at home. However, more women started growing food at home since COVID-19 than men: $59.3 \%$ of new gardeners were women, and only $39.6 \%$ were men, with $1.1 \%$ identifying as non-binary. The gender divide for long-time home food gardeners was an almost even split: $51.1 \%$ female and $48.6 \%$ male, with $0.23 \%$ of respondents identifying as neither male nor female.

\subsubsection{Age}

The overwhelming majority of new home food growers are millennials; $46.2 \%$ of new gardeners are individuals between the ages of 24 and 38 . This is compared to the $31.7 \%$ of long-time millennial gardeners. 20.9\% of new gardeners are Generation Xers (30 to 53 years old), compared to $21.7 \%$ of long-term gardeners. While baby boomers ( 54 to 72 years old) account for $37 \%$ of long-time gardeners, the highest percentage, only $30.8 \%$ of new home 
food gardeners are baby boomers. No respondents over the age of 73 started gardening during the pandemic, though this age group accounts for $5.7 \%$ of long-time gardeners. Not surprisingly, a greater proportion of the youngest demographic, 23 years old and younger, and the oldest demographic, 73 years old and older, are not home food gardeners.

\subsubsection{Education}

Half of all home-food gardeners have at least one university-award qualification, such as a degree or certificate. $59.4 \%$ of respondents who started home food gardening during the COVID-19 pandemic have a university education. $24.9 \%$ of long-time gardeners have a college or other non-university diploma or certificate, while only $17.6 \%$ of new gardeners have a college qualification. The other categories of highest level of education are consistent across long-time gardeners, new gardeners, and non-gardeners. Interestingly, respondents with a high school diploma as their highest level of education grow food at home more than twice as much as those with a trade certificate or diploma as their highest level of education. A possible explanation for these results is that trades tend to be paid by the hour and are, on the whole, considered essential workers during a pandemic, and thus had just as much work or more while many other individuals had more time at home.

\subsubsection{Household Income}

$44.7 \%$ of individuals who have an annual household income of $\$ 75,000$ to $\$ 149,000$ grow food at home, versus the $40 \%$ of individuals in the same income bracket who do not. However, $16.2 \%$ of respondents who have an annual household income of less than $\$ 35,000$ do not grow food at home, versus the $8.2 \%$ of individuals in the same income bracket who do have home food gardens. There is little to no difference in annual household income levels between long-time gardeners and those who started gardening during the COVID-19 pandemic.

The number of condominium and apartment home food gardeners is also on the rise. $24.2 \%$ of new home food gardeners live in an apartment or condominium, versus only $13.5 \%$ of long-time gardeners. $27.5 \%$ of new home food producers grow at least one fruit or vegetable on a balcony, while only $16.7 \%$ of long-time gardeners do so. Findings like these presents a unique opportunity for condo boards, renters' groups, and neighborhood organizations to start home food growing associations. Overall, $86.2 \%$ of respondents that grow their own food indicated that they do so in the back yard of single-dwelling units. The average size of a backyard garden is $21.6 \mathrm{~m}^{2}$. Studies should be carried out specifically focusing on small-pot and container gardening among condo and apartment residents, as well as feasibility studies for rooftop and/or courtyard gardens. Resident-building based community gardens could also be an opportunity worthy of investigation.

\subsubsection{Geographic Region}

Figure 1 illustrates the percentage of home food gardeners versus non-gardeners by region. The Prairies and British Columbia have the highest percentage of gardeners versus non-gardeners; however, Ontario, Canada's most populous province with the highest urban population in the country, is almost exactly split between gardeners and non-gardeners. Out of the respondents who grow food at home who live in Atlantic Canada, 23.7\% of respondents started gardening this year. It is the highest proportion of new gardeners within a region in the country. $87.2 \%$ of Prairie residents who grow food at home have done so for more than a year.

\subsubsection{Ideal Gardener}

While gardening information is accessible to everyone in Canada, there is one group who is more likely to have been gardening for the long-term. Generally, these individuals are middle income earners, with higher levels of education, either male or female who have a backyard. However, new gardeners who have taken up gardening due to the conditions caused by the global COVID-19 pandemic are younger, span income brackets and do not 
necessarily have a backyard. Whether these new gardeners will continue to grow food once the pandemic is over and the competition for disposable income increases remains to be seen.

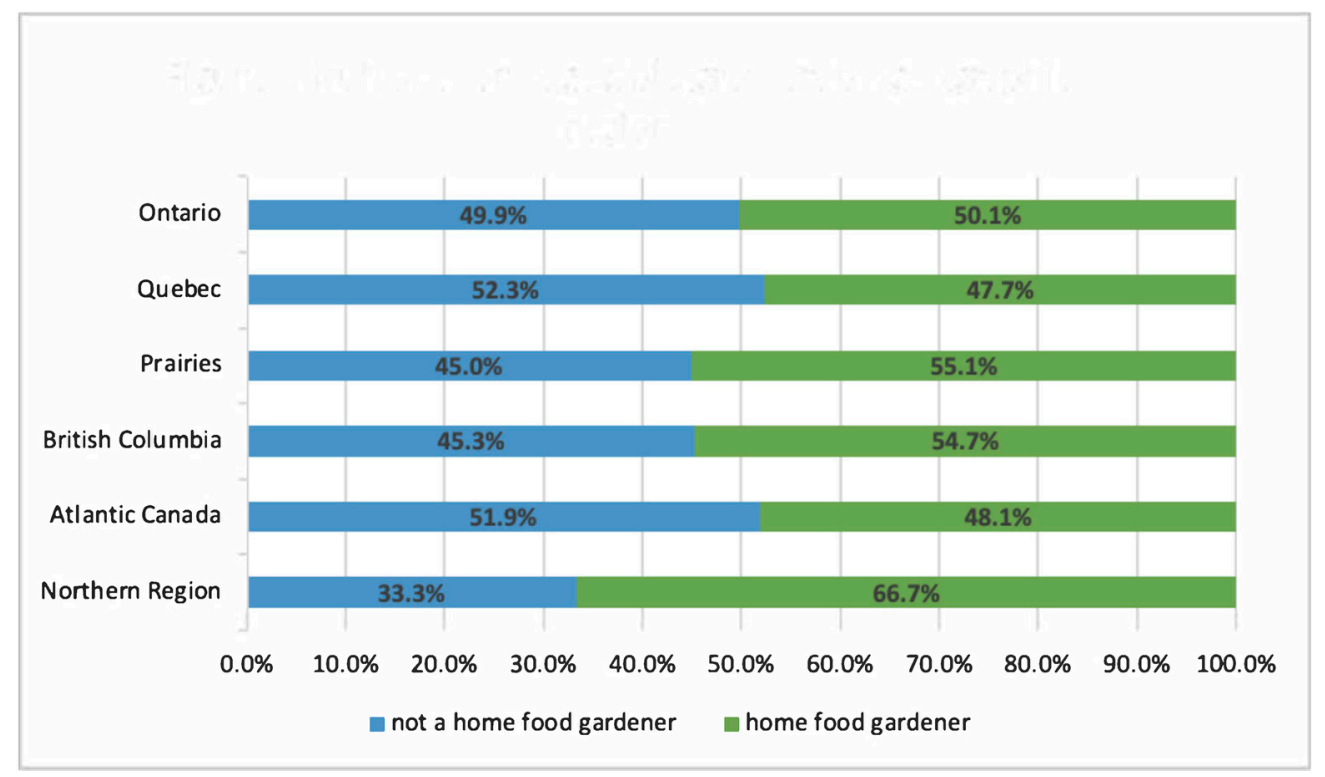

Figure 1. Fruit and/or vegetable growers by geographic region.

\subsection{Eating Home-Grown Fruits and Vegetables}

Canadian home food gardeners grow substantially more vegetables than they do fruit, which, given Canada's short summers, makes sense. Additionally, many common fruits enjoyed by Canadians like apples and pears grow on trees than in the ground or on vines and bushes. Interestingly, long-time gardeners and new gardeners grow the same type of produce in their garden in almost the same ratios. This survey asked gardeners to indicate all of the different kinds of fruits and/or vegetables they grow; the final option asked respondents to list any produce not on the list. $89.3 \%$ of home food gardeners grow tomatoes, making it by far the most popular crop. $57.9 \%$ cent grow lettuce, the next most popular vegetable, followed by cucumbers at $54.6 \%$. Tomatoes and lettuce make sense as the most popular, given that they can be grown in garden beds and pots, inside the home or out. Rounding out the ten most popular fruits and vegetables grown at home were bell peppers, beans, carrots, green onions, peas, onions, and potatoes.

Participants in this study were asked to state what they did with the fruits and/or vegetables they harvested from their home garden and $96 \%$ said they ate their harvest fresh from their garden. Long-term gardeners were more likely to preserve/store and share their produce with friends and family than new gardeners, reasons for which will be discussed when attitudes and beliefs about home food produce are examined.

Gardeners were also asked to think about how many fruits and/or vegetables were consumed by their household in the past month and estimate how much of their monthly produce consumption came from their home garden (As Canada has a short growing season due to its geographic location in the North, the survey was conducted during the first week of October, peak harvest time in Canada.). Surprisingly, $26.4 \%$ of gardeners who only started growing food at home this year got a quarter of their monthly household produce from their gardens (see Figure 2). 


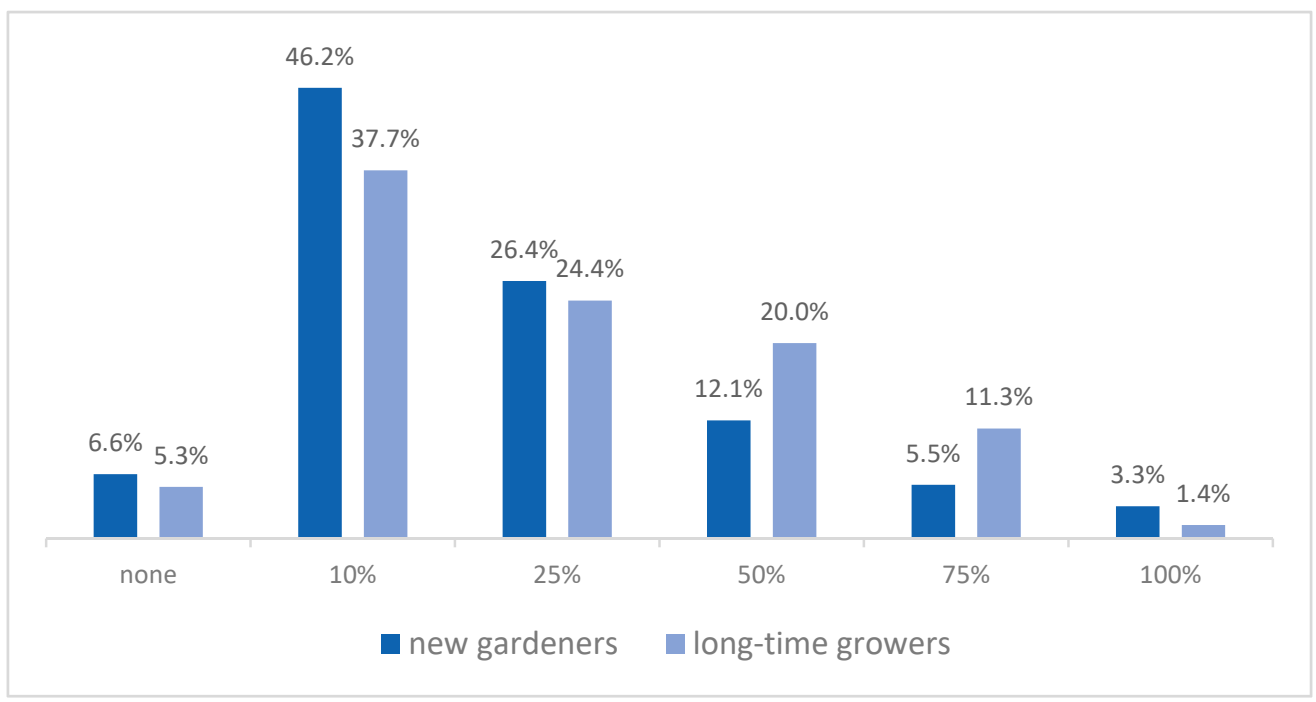

Figure 2. Percent of total household monthly fruit and/or vegetable consumption supplied by home food gardens, by gardener type.

\subsection{Attitudes and Beliefs about Home Food Gardening}

In general, long-time home food gardeners are more definite in their beliefs and attitudes about home food production, answering that they strongly agree or strongly disagree rather than the somewhat agree/disagree options. This is to be expected, as these individuals have been growing their own food for over a year, or, in some cases, for many years as it is a family tradition. Canadians who started gardening during the COVID-19 pandemic have only had one Spring, Summer, and Fall to work in their garden and reap the rewards: they are most likely still evaluating their beliefs as they gain more experience with home food production.

Out of the 14 questions concerning attitudes and beliefs about home food gardening in Canada, the only area of agreement between all gardeners was environmental impact. Over $50 \%$ agree that they grow food at home to reduce their environmental footprint, while $27.4 \%$ of respondents neither agree nor disagree. $13.7 \%$ of respondents strongly disagree that environmental impact concerns play a part in their reasons for growing food at home.

Respondents were asked the relative importance of family traditions and children's well-being in their decision to home food garden and results are quite different between long-term home food gardeners and those who started gardening in 2020, during the pandemic. $63.6 \%$ of long-time gardeners agree that food gardening is a family tradition, and $43 \%$ agree that they continue this tradition because they believe gardening teaches their children new skills and knowledge. $29.8 \%$ of long-term gardeners indicated they did not have children. That being said, $54 \%$ of respondents also agreed that they grow food at home to gain new skills for themselves.

In contrast, $44 \%$ of new gardeners agreed that growing food at home was a family tradition, and only $36.3 \%$ agreed that they did so in part to enrich their children's lives. $41.8 \%$ of new gardeners do not have children. Almost three-quarters of new gardeners, $69.3 \%$, indicated that they started gardening to acquire new skills and knowledge for themselves. It is logical that significantly more new gardeners feel strongly about learning new abilities by gardening, given that family tradition and the presence of children are not as significant motivating factors as they are for long-time gardeners.

Somewhat surprisingly, long-term gardeners are more concerned about food safety than those who started gardening during the global pandemic. Food safety is a prevalent concern during the current global pandemic, both in terms of adequate supply and actual contamination. Localised outbreaks of COVID-19 in meat processing facilities in some provinces forced facility closures and short-term meat shortages in some areas. These outbreaks fed Canadian consumer fears that the food supply could be tainted. Taken 
together with early media reports that the virus can exist for days on plastic surfaces, this created widespread anxiety that grocery stores could become COVID-19 transmission hot spots and that the food itself might infect consumers in their homes [43]. 51.8\% of long-time home food gardeners agree that one reason why they grow food at home is because it is safer than store-bought food. $42.9 \%$ of gardeners who started gardening during the pandemic agree food safety played a role in their decision to grow their own food; interestingly, $25 \%$ of all gardeners have no opinion regarding food safety. Related to food safety is the question of health: respondents were asked if they grew food at home because it was healthier than food purchased from food retailers. $66.9 \%$ of long-time gardeners and $56.1 \%$ of new gardeners agreed.

Home food gardeners overwhelming agree that home-grown produce is more flavourful and tastes better than food purchased at a grocery store or even from a farmer's market. $48.5 \%$ of long-term gardeners strongly agree with this statement, and another $32.7 \%$ somewhat agree. In contrast, $34.1 \%$ of those gardeners who started growing food at home during the COVID-19 pandemic strongly agree that their fruits and/or vegetables taste better than those that they buy, with an additional $38.5 \%$ somewhat agreeing.

All home food gardeners agree that gardening is important for mental and physical well-being, though long-time gardeners are more likely to cite these are reasons for gardening. Among long-time growers, $70.6 \%$ agree that they garden for relaxation and $57.6 \%$ considering gardening to be good physical exercise. Following the general trends in this study, $61.6 \%$ of new gardeners agree they grow food for relaxation and $46.2 \%$ believe it to be good exercise.

The survey asked respondents several questions related to money matters during the COVID-19 pandemic. $85.3 \%$ of all respondents said they believe food prices are increasing due to the ongoing pandemic. More new gardeners, at $89.1 \%$, than long-time gardeners, $84.7 \%$, agree that the pandemic is driving food prices up. Moreover, $41.8 \%$ of new gardeners have lost income because of the pandemic, compared to $34.7 \%$ of long-time home food gardeners. However, when asked if one motivation for growing food at home was to save money, just over half of both new and long-time gardeners agreed.

\section{Discussion}

There is a sizeable amount of data in this survey, which has the potential to impact different aspects of Canadian socio-cultural and land use practices and policies. The results of the study have possible implications for land use policy in densely populated cities. $24.4 \%$ of long-time home food gardeners live in the urban core of a city; the percentage of urban gardeners is higher among new home food gardeners, at $29.7 \%$. The prevalence of urban agriculture as suggested by this study presents opportunities for innovative municipal programs, like the one the City of Brampton launched in April 2020. The Backyard Garden Program, an extension of Brampton's community garden program, encourages residents to start food gardens at home, and donate excess produce to local food banks and community organizations; the municipal government provides free startup soil and seeds to participants [44]. Additionally, $41.5 \%$ of non-gardeners claim the lack of space is why they do not grow food at home (versus the $25 \%$ who stated they are just not interested). With more and more Canadians living in urban areas, municipal governments need to increase awareness of their community gardens: only $2.2 \%$ of respondents had ever gardened in a community garden, yet every major city in Canada has a community garden program, some of which are quite extensive, offering financial support for tools and seeds in addition to the free use of municipal land. With the rise of container and pot gardening, there is also opportunities for municipalities to increase their green footprint and provide gardening space by using the rooftops of community buildings, like libraries and recreation centers. Studies should be conducted among city residents to discover the level of interest in growing their own food in a community garden.

This survey revealed that, for many individuals, home food gardening is a social activity, a skill that is taught through person-to-person interaction. Among gardeners, 
$89.1 \%$ of long-term gardeners indicated that they preserve or store part of their garden's harvest, compared to only $11 \%$ of new gardeners. A possible explanation for this disparity is suggested by the responses to the question of where home food gardeners acquired their preserving knowledge: $77 \%$ claim that family members taught them how to preserve and store fresh fruit and vegetables. As mentioned, new home food gardeners are less likely to have started gardening because of family tradition, so these individuals are less likely to have a family member as a source of information. Additionally, this survey asked gardeners where they acquired seeds and/or plant transplants: $46 \%$ of long-time gardeners got seeds and/or transplants from a family or friend, whereas only $39.6 \%$ of new gardeners did the same. Almost two-thirds of all gardeners responded that they visited expert websites to help solve gardening problems and answer questions; the same percentage of gardeners indicated that family members and friends were a source of information. Just over $20 \%$ of respondents indicated that they also turned to neighbors to problem-solve home food growing issues. However, only $13.2 \%$ of home food gardeners who started gardening during the COVID-19 pandemic said they turned to other gardeners or a community gardening group for help with their gardening questions, versus $26 \%$ of long-time gardeners. Given the restrictions in place across Canada during the pandemic, this is not that surprising. However, the clear desire to interact with other people rather than print or online material indicates a desire for social gardening groups: gatheringswhether online to abide by pandemic guidelines or in person-for individuals to connect with others who share their interest in home food production.

Results suggest that targeting home food gardening outreach and education to lowerincome households on the basis of food security is not any more significant than encouraging all households to grow some food at home. This survey shows that there is some correlation between food security and home food gardening, but few households are able to supply their total monthly produce needs from a home garden (less than $5 \%$ of home gardeners). Food insecurity is impacted, as this study suggests that access to fresh food has increased through gardening. This also study reveals that households do save some money by growing their own fruits and vegetables, however, these are not significant savings, as, regardless of if you are a home food gardener or not, $96 \%$ of respondents get at least some of their fruit and vegetables from a grocery store. Whether the financial benefits of investing in gardening is greater than simply using those finances towards monthly food expenditures needs further study.

Finally, this study revealed beliefs about Canada's food supply chain systems, as over half of the total respondents stated they are concerned about food shortages during the pandemic. Since the beginning of the COVID-19 pandemic, there has been an increased scrutiny of the Canadian food supply system. Fears of food shortages have led consumers to panic buy and stockpile non-perishable food stuffs and household products. There were concerns that the pandemic would have a negative impact on the supply of fresh fruits and vegetables, as farmers struggled with migrant worker shortages [45]. Such fears proved unfounded; however, $85.1 \%$ of respondents still feel that food prices have risen because of COVID-19. Uncertainty and misunderstanding with regard to food supply chain systems are sources of anxiety for Canadians: with no end in sight of the COVID-19 pandemic, there is ample opportunity for all stakeholders in food supply chain to reach out to Canadians with explanations and education around where food comes from and how food gets to grocery stores.

\section{Conclusions}

This exploratory study was completed at the end of the first summer of the COVID-19 pandemic in Canada, after most of Canada's citizens were under lockdown from midMarch 2020 to June 2020, to prevent and control the spread of the disease. The results of our study agreed with much of the scant scholarly literature on home food gardening. However, there are real divergences of gardening practices and attitudes about home food production between long-time gardeners and those individuals who started gardening 
in 2020 during the COVID-19 pandemic, with many of these divergences traced to the upheavals in everyday life caused by the pandemic. While this study focused solely on Canadian gardeners, implications for the broader global context will be similar as many countries experienced similar lockdowns and closures.

In order to gain more insight into just how significant a cause the pandemic lockdown was on home food gardening, follow-up surveys should be completed September 2021 and September 2022 to discover if as many Canadians are still growing food at home and to investigate if more households have started home food gardens. Until at least a year has passed, it is impossible to assess if the COVID-19-caused surge in home food gardening is a long-lasting lifestyle change or just a fad.

Author Contributions: Conceptualization, S.C., J.M. and E.F.; methodology, J.M.; software, E.F. and J.M.; validation, S.C., E.F. and J.M.; formal analysis, J.M.; writing-original draft preparation, E.F. and L.M.; writing-review and editing, L.M. and J.M.; supervision, S.C.; project administration, J.M.; funding acquisition, S.C. All authors have read and agreed to the published version of the manuscript.

Funding: This work was supported by the Social Sciences and Humanities Research Council under Grant \#435-2017-0901, 2019.

Institutional Review Board Statement: The study was conducted according to the guidelines of the Declaration of Helsinki and approved by the Institutional Review Board (or Ethics Committee) of Dalhousie University (protocol code 2020-5230) on 22 July 2020.

Informed Consent Statement: Informed consent was obtained from all subjects involved in the study.

Data Availability Statement: Restrictions apply to the availability of these data. Please contact the corresponding author with requests for access to these data.

Conflicts of Interest: The authors declare no conflict of interest.

\section{References}

1. Klinkenberg, M. Seed Companies Thought Coronavirus Would Ruin Their Businesses. Instead, Demand Has Soared. The Globe and Mail. 1 June 2020. Available online: https:/ /www.theglobeandmail.com/life/article-peis-veseys-sees-demand-soar-ascovid-19-spurs-vegetable-seeds-frenzy / (accessed on 1 March 2021).

2. Helmore, E. Americans Turn to Home-Farming as They Fear for Their Food Supply. The Guardian. 6 June 2020. Available online: https:/ / www.theguardian.com/world/2020/jun/06/food-insecure-americans-are-home-farming-as-covid-wreakshavoc-on-agricultural-chain (accessed on 1 March 2021).

3. Helmer, J. How the Coronavirus Pandemic Has Led to a Boom in Crisis Gardening. HuffPost Canada. 3 April 2020. Available online: https: / / www.huffpost.com/entry/seeds-crisis-gardening-coronavirus-food_n_5e85eca0c5b6f55ebf492212 (accessed on 1 March 2021).

4. Brehaut, L. Boom in Pandemic Gardening Has Led to Shortage of Mason Jars and Lids. National Post. 8 October 2020. Available online: https:/ / nationalpost.com/life/food/boom-in-pandemic-gardening-has-led-to-shortage-of-mason-jars-and-lids (accessed on 1 March 2021).

5. Brewster, M. Canadians are Being Asked to Stop Panic-Shopping. Are They Listening? CBC News. 19 March 2020. Available online: https: / www.cbc.ca/news/politics/covid-19-pandemic-coronavirus-border-panic-1.5502058 (accessed on 1 March 2021).

6. Dryden, J.; Rieger, S. Inside the Slaughterhouse. CBC News. 6 May 2020. Available online: https://newsinteractives.cbc.ca/ longform/cargill-covid19-outbreak (accessed on 1 March 2021).

7. Hobbs, J.E. Food supply chains during the COVID-19 pandemic. Can. J. Agric. Econ. Can. Agroecon. 2020, 68, 171-176. [CrossRef]

8. Carbone, A. Food supply chains: Coordination governance and other shaping forces. Agric. Food Econ. 2017, 5, 3. [CrossRef]

9. Charlebois, S.; Sterling, B.; Haratifar, S.; Naing, S.K. Comparison of Global Food Traceability Regulations and Requirements. Compr. Rev. Food Sci. Food Saf. 2014, 13, 1104-1123. [CrossRef]

10. Statistics Canada. Table 38-10-0025-01: Homegrown Fruit, Herbs, Vegetables and Flowers. 2017. Available online: https: / / www150.statcan.gc.ca/t1/tbl1/en/tv.action?pid=3810002501 (accessed on 1 March 2021).

11. City Farmer. 40\% of Toronto Households Grow Food. 6 November 2002. Available online: http:// cityfarmer.org/40percent.html (accessed on 4 March 2021).

12. Duchemin, E. Cartographie des jardins potagers individuels dans l'arrondissement Rosemont Petite-Patrie (Montréal). AgirUrbain. 22 November 2019. Available online: https:/ / agriurbain.hypotheses.org/4192 (accessed on 1 March 2021).

13. Guitart, D.; Pickering, C.; Byrne, J. Past results and future directions in urban community gardens research. Urban For. Urban Green. 2012, 11, 364-373. [CrossRef] 
14. Taylor, J.R.; Lovell, S.T. Urban home gardens in the Global North: A mixed methods study of ethnic and migrant home gardens in Chicago, IL. Renew. Agric. Food Syst. 2014, 30, 22-32. [CrossRef]

15. Cochran, S.; Minaker, L. The Value in Community Gardens: A Return on Investment Analysis. Can. Food Stud. 2020, 7, 126-149. [CrossRef]

16. Kortright, R.; Wakefield, S. Edible backyards: A qualitative study of household food growing and its contributions to food security. Agric. Hum. Values 2010, 28, 39-53. [CrossRef]

17. Brooks, S.K.; Webster, R.K.; Smith, L.E.; Woodland, L.; Wessely, S.; Greenberg, N.; Rubin, G.J. The psychological impact of quarantine and how to reduce it: Rapid review of the evidence. Lancet 2020, 395, 912-920. [CrossRef]

18. Smith, V.M.; Greene, R.B.; Silbernagel, J. The social and spatial dynamics of community food production: A landscape approach to policy and program development. Landsc. Ecol. 2013, 28, 1415-1426. [CrossRef]

19. OkvatAlex, H.A.; Zautra, A.J. Community Gardening: A Parsimonious Path to Individual, Community, and Environmental Resilience. Am. J. Community Psychol. 2011, 47, 374-387. [CrossRef]

20. Saguin, K. Cultivating beneficiary citizenship in urban community gardens in Metro Manila. Urban Stud. 2020, 57, 3315-3330. [CrossRef]

21. Gregory, M.M.; Leslie, T.W.; Drinkwater, L.E. Agroecological and social characteristics of New York city community gardens: Contributions to urban food security, ecosystem services, and environmental education. Urban Ecosyst. 2015, 19, 763-794. [CrossRef]

22. Al-Delaimy, W.K.; Webb, M. Community Gardens as Environmental Health Interventions: Benefits Versus Potential Risks. Curr. Environ. Health Rep. 2017, 4, 252-265. [CrossRef]

23. Alaimo, K.; Beavers, A.W.; Crawford, C.; Snyder, E.H.; Litt, J.S. Amplifying Health Through Community Gardens: A Framework for Advancing Multicomponent, Behaviorally Based Neighborhood Interventions. Curr. Environ. Health Rep. 2016, 3, 302-312. [CrossRef]

24. Hartwig, K.A.; Mason, M. Community Gardens for Refugee and Immigrant Communities as a Means of Health Promotion. J. Community Health 2016, 41, 1153-1159. [CrossRef] [PubMed]

25. Kumar, B.; Nair, P. The enigma of tropical homegardens. Agrofor. Syst. 2004, 61-62, 135-152. [CrossRef]

26. Algert, S.; Diekmann, L.; Renvall, M.; Gray, L. Community and home gardens increase vegetable intake and food security of residents in San Jose, California. Calif. Agric. 2016, 70, 77-82. [CrossRef]

27. Schupp, J.L.; Sharp, J.S. Exploring the social bases of home gardening. Agric. Hum. Values 2011, 29, 93-105. [CrossRef]

28. Nisar, M.; Idress, M. Underlining Small Farmers' Home Gardening Need in District Tank, Khyber Pakhtunkhwa, Pakistan. Sarhad J. Agric. 2019, 35, 1138-1143. [CrossRef]

29. Larder, N.; Lyons, K.; Woolcock, G. Enacting food sovereignty: Values and meanings in the act of domestic food production in urban Australia. Local Environ. 2012, 19, 56-76. [CrossRef]

30. Phulkerd, S.; Thapsuwan, S.; Gray, R.S.; Chamratrithirong, A. Characterizing Urban Home Gardening and Associated Factors to Shape Fruit and Vegetable Consumption among Non-Farmers in Thailand. Int. J. Environ. Res. Public Health 2020, 17, 5400. [CrossRef]

31. Singh, R.K.; Rallen, O.; Padung, E. Elderly Adi Women of Arunachal Pradesh: "Living Encyclopedias" and Cultural Refugia in Biodiversity Conservation of the Eastern Himalaya, India. Environ. Manag. 2013, 52, 712-735. [CrossRef] [PubMed]

32. Gray, L.; Guzman, P.; Glowa, K.M.; Drevno, A.G. Can home gardens scale up into movements for social change? The role of home gardens in providing food security and community change in San Jose, California. Local Environ. 2014, 19, 187-203. [CrossRef]

33. Needham, T. Faculty of Forestry and Environmental Management University of New Brunswick-Canada. Int. J. For. Eng. 2002, 13, 57. [CrossRef]

34. Reese, A.M. "We will not perish; we're going to keep flourishing": Race, Food Access, and Geographies of Self-Reliance. Antipod 2018, 50, 407-424. [CrossRef]

35. Galhena, D.H.; Freed, R.; Maredia, K.M. Home gardens: A promising approach to enhance household food security and wellbeing. Agric. Food Secur. 2013, 2, 8. [CrossRef]

36. Glavan, M.; Schmutz, U.; Williams, S.; Corsi, S.; Monaco, F.; Kneafsey, M.; Rodriguez, P.A.G.; Čenič-Istenič, M.; Pintar, M. The economic performance of urban gardening in three European cities-Examples from Ljubljana, Milan and London. Urban For. Urban Green. 2018, 36, 100-122. [CrossRef]

37. Baumgarten, B. Back to Solidarity-Based Living? The Economic Crisis and the Development of Alternative Projects in Portugal. Partecip. Confl. 2017, 10, 169-192. [CrossRef]

38. National Gardening Association. Garden to Table: A 5-Year Look at Food Gardening in America; National Gardening Association: Williston, VT, USA, 2014. Available online: https://garden.org/special/pdf/2014-NGA-Garden-to-Table.pdf (accessed on 1 March 2021).

39. Hoenig, J. Garden Variety: The American Tomato from Corporate to Heirloom; Columbia University Press: New York, NY, USA, 2017; ISBN 978-0-231-54638-6.

40. Mosby, I. Food will Win the War: The Politics, Culture and Science of Food on Canada's Home Front; UBC Press: Vancouver, ON Canada, 2014.

41. Statistics Canada. Food Insecurity during the Covid-19 Pandemic. 2020. Available online: https://www150.statcan.gc.ca/n1 / pub /45-28-0001/2020001/article/00039-eng.pdf (accessed on 5 August 2020). 
42. Huisken, A.; Orr, S.K.; Tarasuk, V. Adults' food skills and use of gardens are not associated with household food insecurity in Canada. Can. J. Public Health 2016, 107, e526-e532. [CrossRef]

43. McEwan, K.; Marchand, L.; Shang, M.; Bucknell, D. Potential implications of COVID-19 on the Canadian pork industry. Can. J. Agric. Econ. Can. Agroecon. 2020, 68, 201-206. [CrossRef]

44. City of Brampton. City of Brampton Announces First Citywide Backyard Garden Program in Canada in Response to COVID-19. Brampton. 16 April 2020. Available online: https:/ / www.brampton.ca/EN/City-Hall/News/Pages/Media-Release.aspx/734 (accessed on 1 March 2021).

45. Jámbor, A.; Czine, P.; Balogh, P. The Impact of the Coronavirus on Agriculture: First Evidence Based on Global Newspapers. Sustainability 2020, 12, 4535. [CrossRef] 